7. Плешков Б. П. Практикум по биохимии растений. Москва. 1968. 183 с.

8. Половникова М. Г., Воскресенская О. Л. Активность компонентов антиоксидантной защиты и полифенолоксидазы у газонных растений в онтогенезе в условиях городской среды // Физиология растений. 2008. Т. 55. № 5. С. 777-785.

9. Россихіна-Галича Г. С. Прооксидантно-антиоксидантна рівновага насіння Fraxinus excelsior L. в умовах міського середовища // Вісник Львів. ун-ту. Серія біологічна. 2013. Вип. 61. С. 195-200.

10. Россихіна Г. С., Лихолат Ю. В., Кирпита Л. В. Активність ферментів-детоксикаторів активних форм кисню газоноутворюючих трав за комплексної дії токсикантів // Вісник Львів. ун-ту. Серія біологічна. 2011. Вип 56. С. 239-244.

11. Чиркова T. B. Физиологические основы устойчивости растений. Санкт-Петербург. 2002. $244 \mathrm{c}$.

12. Сезонна динаміка антиоксидантних процесів у листках Acer negundo за дії полютантів / Н. О. Хромих та ін. // Вісник Дніпропетр. ун-ту. 2014. № 22 (1). Серія. Біологія, екологія. С. 71-76.

Надійшла до редколегії 14.03.2016

УДК 574.472

О. В. Потапенко ${ }^{1,2}$, Д. С. Ганжа ${ }^{3}$, О. В. Жуков ${ }^{1,4}$

${ }^{1}$ - Дніпропетровський державний аграрно-економічний університет 2 - ДТЕК Дніпробленерго

3 - Природний заповідник «Дніпровсько-Орільський»

${ }^{4}$ - Дніпропетровський національний університет імені Олеся Гончара

\title{
ЕКОМОРФІЧНИЙ АНАЛІЗ РОСЛИННОГО ПОКРИВУ ТЕРИТОРІЙ ЕЛЕКТРИЧНИХ ПІДСТАНЦЙ
}

Досліджено рослинний покрив на територіях енергетичних підстанцій, встановлено особливості їх екоморфічної організації та визначено напрямки трансформації рослинного покриву за умов забруднення грунту технологічною олією. У результаті проведеного дослідження встановлено, що на території ділянок електричних підстанцій видовий склад угруповань рослин представлений 118 видами. В контрольних умовах середне значення проективного покриття рослинності становить $79,68 \%$. За умов забруднення грунту технологічною олісю проективне покриття рослинності значно знижується до рівня 7,16 \%. Основними трендами трансформації екологічної структури біогеоценотичного покриву за умов забруднення грунту технологічною олією є збільшення частки однорічних рудерантів, аридизація режиму вологості та збіднення ефективної родючості едафотопу.

Ключові слова: екоморфічний аналіз, рослинний покрив, енергетичні підстанції, біорізноманіття.

1,2 О. В. Потапенко, ${ }^{3}$ Д. С. Ганжа, ${ }^{1,4}$ А. В. Жуков

${ }^{1}$ - Днепропетровский государственный аграрно-економический университет ${ }^{2}$ - ДТЕК Днепроблэнерго

3 - Природный заповедник "Днепровско-Орельский»

${ }^{4}$ - Днепропетровский национальный университет имени Олеся Гончара

\section{ЭКОМОРФИЧЕСКИЙ АНАЛИЗ РАСТИТЕЛЬНОГО ПОКРОВА ТЕРРИТОРИЙ ЭЛЕКТРИЧЕСКИХ ПОДСТАНЦИЙ}

Исследован растительный покров на территориях энергетических подстанций, установлены особенности их экоморфической организации и определены направления трансформации растительного покрова в условиях загрязнения почвы техноло-

(C) О. В. Потапенко, Д. С. Ганжа, О. В. Жуков, 2016 
гическим маслом. В результате проведенного исследования установлено, что на территории участков электрических подстанций видовой состав сообществ растений представлен 118 видами. В контрольных условиях среднее значение проективного покрытия растительности составляет 79,68 \%. В условиях загрязнения почвы технологическим маслом проективное покрытие растительности значительно снижается до уровня 7,16 \%. Основными трендами трансформации экологической структуры биогеоценотического покрова в условиях загрязнения почвы технологическим маслом являются увеличение доли однолетних рудерантов, аридизация режима влажности и обедненность эффективного плодородия эдафотопа.

Ключевые слова: экоморфический анализ, растительный покров, энергетические подстанции, биоразнообразие.

\section{O. V. Potapenko ${ }^{1,2}$, D.S. Ganzha ${ }^{3}$, A.V. Zhukov ${ }^{1,4}$ \\ ${ }^{1}$ - Dnipropetrovsk State Agrarian and Economic University ${ }^{2}$ - DTEK Dniprooblenergy ДТЕК \\ 3 - Nature reserve «Dneprovsko-Orylskiy» \\ ${ }^{4}$ - Oles Honchar Dnipropetrovsk National University \\ THE ECOMORPHIC ANALISIS OF THE VEGETATIONS ON THE POVER SUBSTANTIONS PLACE}

The vegetation within the territories of power substations has been investigated in present work. The features of vegetation ecomorphic oganization have been revealed and the direction of vegetation transformation under soil pollution by technologic oil have been considered. The study found that on the territory of sectors of electrical substations species composition of plant communities represented by 118 species. The average value of the projection cover of vegetation is $\mathbf{7 9 , 6 8} \%$ in control condition. In terms of soil pollution oil coating vegetation projective technology greatly reduced to the level of 7,16\%. The main trends of the transformation of the ecological structure of biogeocenotic cover in terms of soil pollution oil technology are increasing the proportion of annual ruderants, humidity regime aridization and depletion of the effective fertility of ecotope.

Keywords: ecomorphic analysis, vegetation, power substations, biodiversity.

ПАТ «ДТЕК Дніпрообленерго» - це найбільша енергопостачальна компанія в Україні, яка займається двома видами діяльності: передача та постачання електроенергіi. Підприємство обслуговує регіон площею майже 32 тис. км², забезпечує електрикою більше ніж 40 тис. юридичних, а також 1,5 млн. побутових абонентів. Компанія експлуатує 49,7 тис. км ліній електропередачі та більше 12 тис. електричних підстанцій.

Під час процесу передачі та постачання електроенергії можливий вплив на навколишнє природне середовище: на атмосферне повітря, на водні ресурси, на землі, на біорізноманіття тощо.

ПАТ «ДТЕК Дніпрообленерго» усвідомлює свою відповідальність за збереження навколишнього природного середовища, а збереження екологічного балансу є невід'ємною частиною стратегії успішного ведення бізнесу, тому в 2012 p. було прийнято Політику з управління охороною навколишнього середовища. Серед стратегічних цілей компанії - запроваджувати найкращі технології для забезпечення промислової та екологічної безпеки.

Питанням екологічного менеджменту в компанії приділяється особлива увага. Впровадження екологічного стандарту ISO 14001:2004 в ДТЕК проходило в 2012 р. У результаті було розроблено єдині вимоги в галузі охорони навколишнього середовища, ідентифіковано екологічні аспекти та ризики, створено ефективну систему управління ними. Це дозволило закласти міцну основу для подальшої системної природоохоронної діяльності компанії, використовувати інноваційні методи в управлінні охороною навколишнього середовища і постійно підвищувати екологічну результативність. 
Електричні підстанції компанії розташовано на території усієї Дніпропетровської області. Розгалуженість структури зумовлює взаємодію 3 навколишнім середовищем.

Особливий режим функціонування створює умови для вивчення процесу впливу техногенного середовища на біорізноманіття для пошуку балансу між економічним розвитком та збереженням довкілля.

Понад $60 \%$ електричних підстанцій працює більше 25 років і потребує заміни. Це загальна картина в обленерго України, що обумовлена хронічним недофінансуванням галузі протягом 20 років.

Експлуатація оливонаповненого обладнання обумовлює ризик розливів нафтопродуктів. Тому важливо дослідити можливі антропогенні зміни грунтів у районі електричних підстанцій.

Для діагностики грунтів доцільно застосовувати заходи геоботанічної індикації за непрямими ознаками, наприклад, зміни покриття порівняно 3 фоновою ділянкою, випадіння окремих видів, розвитку фітопатологічних відхилень («морф»), змінами в лісовій підстилці та опаді [5].

3 метою ліквідації розливів нафтопродуктів та попередження утворення промащених відходів оливоприймачі 5 трансформаторів у 2013 році на одній 3 підстанцій було оброблено спеціальним складом бактерій, що розкладають нафтопродукти на безпечні речовини.

Технології показали свою ефективність, але є нагальна потреба у розробленні нової доступної за ціною технології відновлення земель, яка може бути виконана фахівцями компанії.

Важливим аспектом екологічної оцінки територій енергетичних підстанцій $€$ визначення їх ролі як локальних рефугіумів біологічного різноманіття. Ці території $є$ режимними об'єктами, які значною мірою екрановані від цілої низки зовнішніх впливів. Їх можна розглядати як елементи територіальної мозаїчності, що формують осередки, які зазнають меншого агротехногенного впливу.

Ми висуваємо гіпотезу, що території енергетичних підстанцій на тлі специфічного екологічного режиму, а саме - підвищений електромагнітний фон та значні ризики потрапляння нафтопродуктів (технологічної олії) у грунт, можуть виконувати роль рефугіумів біологічного різноманіття.

Програма наших досліджень передбачає оцінку показників біологічного різноманіття для двох груп живих організмів, які володіють значним біоіндикаційним потенціалом: рослинні угруповання та угруповання грунтової мезофауни.

Слід зазначити, що існують подібні методологічні засади аналізу особливостей біологічного різноманіття [1-4; 6; 7].

Ключовим принципом дослідження екологічних особливостей рослинного покриву в умовах степової України є екоморфічний аналіз О. Л. Бельгарда $[1 ; 2]$. Можливість застосування принципів екоморфічного аналізу для вирішення питань зоологічної діагностики грунтів була показана О. Л. Бельгардом та А. П. Травлєєвим [3].

Поряд з екоморфічним аналізом значною результативністю володіє методика фітоіндикації [7].

Метою нашої роботи є дослідити рослинний покрив на територіях енергетичних підстанцій, встановити особливості їх екоморфічної організації та встановити напрямки трансформації рослинного покриву за умов забруднення грунту технологічною олією.

\section{Матеріали та методи.}

Дослідження проведені восени 2016 р. Геоботанічний опис проведено на 19 енергетичних підстанціях (рис. 1). У межах кожної підстанції окремо було зроблено геоботанічний опис контрольної ділянки, яка не зазнала негативного впливу розливу технологічної олії, та ділянки з очевидними слідами розливу техноло- 
гічної олії. Крім того, у межах підстанцій здійснено опис у додаткових ділянках. Загальна кількість геоботанічних описів становить 51, 3 яких 22 - для контрольних умов та 29 - для забруднених технологічною олією ділянок. Екоморфи рослин наведено за О. Л. Бельгардом [1] та В. В. Тарасовим [8].

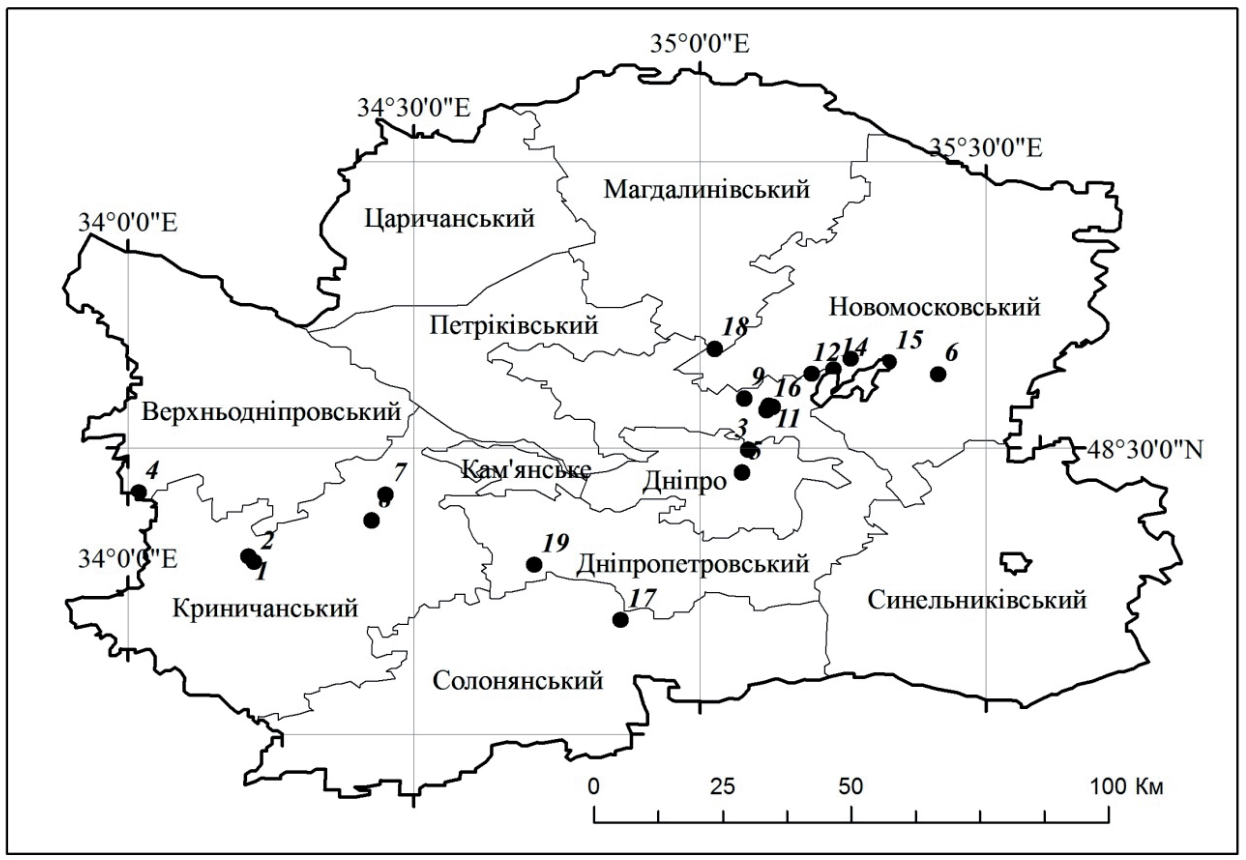

Умовні позначки: 1 - Криничанський РЕМ КТП-325; 2 - Криничанський РЕМ КТП-326; 3 - Підстанція «КЛ - 150 кВ»; 4 - Верхньодніпровський РЕМ КТП-04; 5 - Підстанція «Вузлова - 150 кВ»; 6 - Новомосковський РЕМ КТП-11; 7 - Криничанський РЕМ КТП-85; 8 - Криничанський РЕМ КТП-193; 9 - Дніпропетровський РЕМ КТП-101; 10 - Дніпропетровський РЕМ КТП-81; 11 - Дніпропетровський РЕМ КТП-91; 12 - Новомосковський РЕМ КТП-171; 13 - Новомосковський РЕМ КТП-101; 14 - Новомосковський РЕМ КТП-48; 15 - Новомосковський РЕМ КТП-209; 16 - Дніпропетровський РЕМ КТП78; 17 - Солонянський РЕМ КТП-773; 18 - Новомосковський РЕМ КТП-773; 19 - Солонянський РЕМ КТП-353

Результати та їх обговорення. У результаті проведеного дослідження встановлено, що на території ділянок електричних підстанцій видовий склад угруповань рослин представлений 118 видами рослин. Рослинність представлена двома відділами - Bryophyta (переважно видом синтріхія польова - Syntrichia ruralis (Hedw.) F. Weber \& D. Mohr) та Magnoliophyta (табл. 1). Останній відділ представлений класом Liliopsida (19 видів) та Magnoliopsida (98 видів).

Клас представлено трьома порядками та трьома родинами (Hemerocallidaceae, Cуреraceae, Роасеае), серед яких Роасеае найбільш різноманітний та представлений 17 видами. Найбільш різноманітними за кількістю видів є роди Festuca (3 види) та Роа (4 види). Слід зазначити, що представники вказаних родів відіграють найважливішу роль у ценозі за проективним покриттям. До таких лідерів належать костриця валіська (Festuca valesiaca Goud. s.1.) та тонконіг вузьколистий (Poa angustifolia L.).

Серед Magnoliopsida найбільш багатим видами є родини Asteraceae (28 видів), Fabaceae (9 видів), Lamiaceae (5 видів) та Rosaceae (5 видів).

Розподіл проективного покриття угруповань має значно асиметричний характер (рис. 2, А). Процедура логарифмування дозволила привести розподіл до більш 
наближеної до нормального закону форми (рис. 2, В). Розподіли логарифмованих значень для контрольних та забруднених ділянок вказують на суттєві відмінності у щільності рослинного покриву за різних умов антропогенного навантаження (рис. 2, С).

Таблиця 1

Таксономічна структура угруповання рослин

\begin{tabular}{|l|c|l|c|}
\hline \multicolumn{1}{|c|}{ Таксони } & Кількість видів & \multicolumn{1}{|c|}{ Таксони } & Кількість видів \\
\hline Відділ Bryophyta & 1 & Fabaceae & 2 \\
\hline Клас Polytrichopsida & 1 & Geraniaceae & 1 \\
\hline Polytrichaceae & 1 & Grossulariaceae & 1 \\
\hline Biдділ Magnoliophyta & 117 & Juglandaceae & 5 \\
\hline Клас Liliopsida & 19 & Lamiaceae & 1 \\
\hline Cyperaceae & 1 & Moraceae & 1 \\
\hline Hemerocallidaceae & 1 & Onagraceae & 3 \\
\hline Poaceae & 17 & Papaveraceae & 3 \\
\hline Клас Magnoliopsida & 98 & Plantaginaceae & 1 \\
\hline Aceraceae & 1 & Polygonaceae & 1 \\
\hline Amaranthaceae & 1 & Portulacaceae & 1 \\
\hline Apiaceae & 2 & Ranunculaceae & 5 \\
\hline Asteraceae & 1 & Rhamnaceae & 2 \\
\hline Boraginaceae & 6 & Rosaceae & 3 \\
\hline Brassicaceae & 1 & Rubiaceae & 1 \\
\hline Cannabaceae & 28 & Scrophulariaceae & 1 \\
\hline Caryophyllaceae & 2 & Simaroubaceae & 1 \\
\hline Chenopodiaceae & 1 & Solanaceae & 1 \\
\hline Convolvulaceae & Ulmaceae & \\
\hline Crassulaceae & Violaceae & \\
\hline Dipsacaceae & Vitaceae & \\
\hline Euphorbiaceae & Zygophyllaceae & \\
\hline
\end{tabular}

Для пошуку статистичних оцінок проективного покриття рослинності первинні результати попередньо були логарифмовані, потім піддані статистичному аналізу, після чого статистичні оцінки піддали процедурі експоненціювання. Так як досліджений розподіл не є симетричним, то межі довірчого інтервалу також не є симетричними відносно оцінки середнього значення. В контрольних умовах середне значення проективного покриття рослинності становить 79,68 \%. За умов забруднення грунту технологічною олією проективне покриття рослинності значно знижується до рівня 7,16 \%. Наслідки негативного впливу потрапляння олії у грунт на показники проективного покриття рослинності статистично вірогідні $(F=98,2, p=0,00)$ (табл. 2).

Таблиия 2

Проективне покриття рослинності у межах територій електричних підстанцій

\begin{tabular}{|c|c|c|c|c|}
\hline \multirow{3}{*}{ Ділянки територій } & \multirow{3}{*}{ Об'єм вибірки } & \multicolumn{3}{|c|}{ Проективне покриття, \% } \\
\hline & & \multirow{2}{*}{ середнє } & \multicolumn{2}{|c|}{ довірчий інтервал } \\
\hline & & & $-95,00 \%$ & $+95,00 \%$ \\
\hline Контроль & 22 & 79,68 & 65,07 & 97,56 \\
\hline Забруднення технічною олією & 29 & 7,16 & 4,95 & 10,37 \\
\hline У цілому & 51 & 18,15 & 12,26 & 26,87 \\
\hline
\end{tabular}



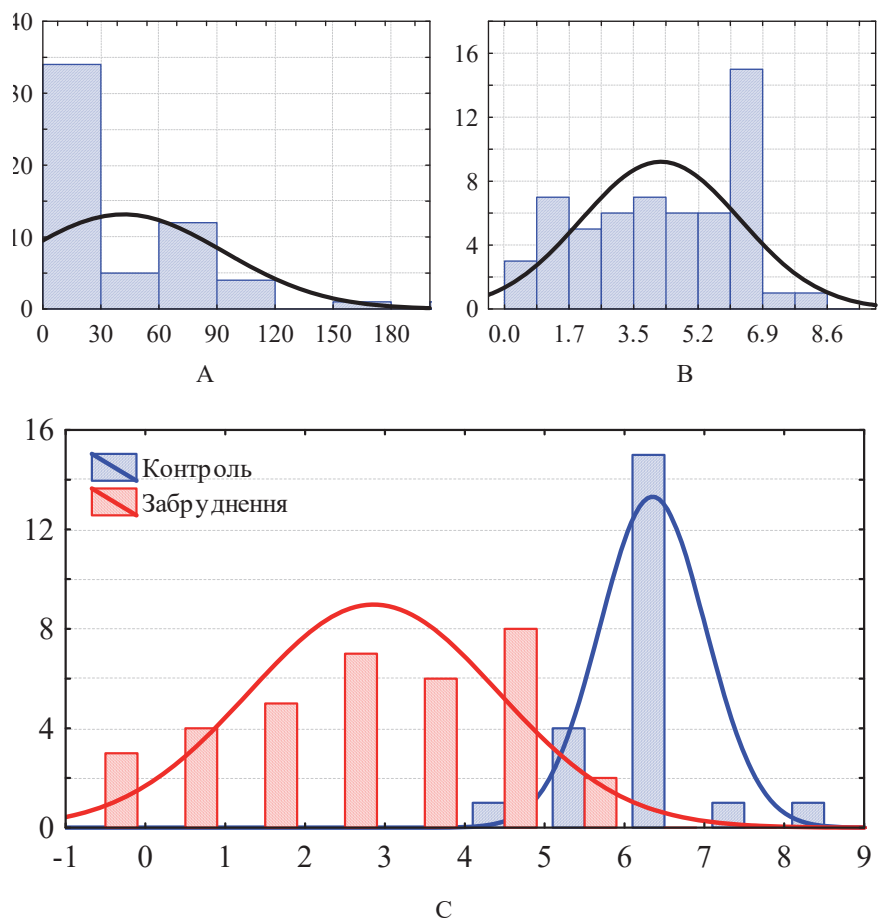

Рис. 2. Гістограми розподілу оцінок проективного покриття рослинності у межах територій електричних підстанцій

Умовні позначки: А - загальний розподіл, у \%; В - загальний розподіл, у логарифмованому масштабі; $\mathrm{C}$ - розподіли у контролі та при забрудненні, у логарифмованому масштабі

Кількісні показники трансформації рослинного покриву у відповідь на забруднення грунту супроводжуються якісними перебудовами екологічної структури. У структурі клімаморф угруповання переважають гемікриптофіти та терофіти. У забруднених ділянках в угрупованні рослин значно зменшується частка багаторічних гемікриптофітів (з 42,80 \% до 36,43 \%) та багаторічних геофітів (з 21,27 \% до 17,85 \%). Очевидно, що цей процес відбувається за рахунок компенсаторного збільшення частки терофітів однорічників (з 29,72 \% до 40,83 \%) (табл. 3). Варіювання інших клімаморф та життєвих форм на фоні їх низької представленості в угрупованні мають підлеглий характер.

Таблиця 3

\section{Структура клімаморф та життєвих форм рослинного покриву територій електричних підстанцій}

\begin{tabular}{|c|c|c|c|c|c|}
\hline \multirow{2}{*}{ Клімаморфи } & \multirow{2}{*}{ Життєві форми } & \multicolumn{2}{|c|}{ Контроль } & \multicolumn{2}{c|}{ Забрудення } \\
\cline { 3 - 6 } & Дер & 1,27 & 1,42 & 0,49 & 4,16 \\
\hline $\mathrm{Ph}$ & Кущ & 0,82 & 0,92 & - & - \\
\hline $\mathrm{nPh}$ & Бр. & 38,23 & 42,80 & 4,26 & 36,43 \\
\hline \multirow{2}{*}{$\mathrm{HKr}$} & Дв & 2,50 & 2,80 & 0,06 & 0,49 \\
\cline { 2 - 6 } & Од & 0,77 & 0,87 & 0,03 & 0,24 \\
\hline & Од & 26,55 & 29,72 & 4,77 & 40,83 \\
\hline $\mathrm{T}$ & Бр. & 19,00 & 21,27 & 2,09 & 17,85 \\
\hline $\mathrm{G}$ & Бр. & 0,18 & 0,20 & - & - \\
\hline $\mathrm{Hel}$ & 89.32 & 100,00 & 11,69 & 100,00 \\
\hline \multicolumn{2}{|c|}{} \\
\cline { 2 - 6 }
\end{tabular}


Екологічна структура угруповання представлена значним діапазоном ценоморф (табл. 4). У контрольних ділянках домінують пратанти (46,62 \%) та степанти $(29,06 \%)$. Також важливу роль в угрупованні відіграють рудеранти (12,98 \%). В умовах забруднення грунту технологічною олією на фоні загального зниження проективного покриття пратанти залишаються домінуючою ценоморфою, але на друге місце виходять рудеранти $(26,16$ \%), які залишають позаду себе степантів $(19,32 \%)$.

Таблиия 4

Структура ценоморф рослинного покриву територій електричних підстанцій

\begin{tabular}{|c|c|c|c|c|}
\hline \multirow{2}{*}{ Ценоморфи } & \multicolumn{2}{|c|}{ Контроль } & \multicolumn{2}{c|}{ Забруднення } \\
\cline { 2 - 5 } & $\begin{array}{c}\text { проективне } \\
\text { покриття, } \%\end{array}$ & $\begin{array}{c}\text { частка } \\
\text { у структурі, \% }\end{array}$ & $\begin{array}{c}\text { проективне } \\
\text { покриття, } \%\end{array}$ & $\begin{array}{c}\text { частка } \\
\text { у структурі, \% }\end{array}$ \\
\hline $\mathrm{Cul}$ & 1,32 & 1,48 & - & - \\
\hline $\mathrm{Pal}$ & 0,64 & 0,71 & 0,14 & 1,22 \\
\hline $\mathrm{Pr}$ & 41,64 & 46,62 & 0,17 & 35,70 \\
\hline $\mathrm{Ps}$ & 5,32 & 5,95 & - & 6,85 \\
\hline $\mathrm{Ptr}$ & 0,05 & 0,05 & 3,06 & - \\
\hline $\mathrm{Ru}$ & 11,59 & 12,98 & 1,26 & 10,76 \\
\hline $\mathrm{Sil}$ & 2,82 & 3,16 & 2,26 & 19,32 \\
\hline $\mathrm{St}$ & 25,95 & 29,06 & 11,69 & 100,00 \\
\hline Усього & 89,32 & 100,00 & & \\
\hline
\end{tabular}

Гігроморфічний спектр угруповань рослин на територіях енергетичних підстанцій досить значний та охоплює рослин від ксерофітів до гігрофітів (табл. 5).

У контрольних умовах домінуючими гігроморфами є ксеромезофіти $(43,21 \%)$ та мезоксерофіти (41,37 \%). На підставі чого можна стверджувати, що гігротоп досліджених біогеоценозів відповідає свіжуватому типу. За умов забруднення грунту технологічною олією відбувається звуження гігроморфічного спектра - зникають гігрофіти та перевагу одержують мезоксерофіти. Це свідчить про аридизацію едафотопу та його відповідність суховатому типу.

Табличя 5

Структура гігроморф рослинного покриву територій електричних підстанцій

\begin{tabular}{|c|c|c|c|c|}
\hline \multirow{2}{*}{ Гігроморфи } & \multicolumn{2}{|c|}{ Контроль } & \multicolumn{2}{c|}{ Забрудення } \\
\cline { 2 - 5 } & $\begin{array}{c}\text { проективне } \\
\text { покриття, } \%\end{array}$ & $\begin{array}{c}\text { частка } \\
\text { у структурі, } \%\end{array}$ & $\begin{array}{c}\text { проективне } \\
\text { покриття, \% }\end{array}$ & $\begin{array}{c}\text { частка } \\
\text { у структурі, \% }\end{array}$ \\
\hline $\mathrm{Ks}$ & 6,18 & 6,92 & 0,74 & 6,36 \\
\hline $\mathrm{MsKs}$ & 36,95 & 41,37 & 5,83 & 49,88 \\
\hline $\mathrm{KsMs}$ & 38,59 & 43,21 & 3,57 & 30,56 \\
\hline $\mathrm{Ms}$ & 6,00 & 6,72 & 0,83 & 7,09 \\
\hline $\mathrm{HgMs}$ & 1,27 & 1,42 & 0,57 & 4,89 \\
\hline $\mathrm{MsHg}$ & 0,14 & 0,15 & 0,14 & 1,22 \\
\hline $\mathrm{Hg}$ & 0,18 & 0,20 & - & - \\
\hline Усього & 89,32 & 100,00 & 11,69 & 100,00 \\
\hline
\end{tabular}

Трофоморфічна структура рослинних угруповань також характеризується значним екологічним діапазоном - від оліготрофів до алькалітрофів (табл. 6). 
Структура трофоморф рослинного покриву територій електричних підстанцій

\begin{tabular}{|c|c|c|c|c|}
\hline \multirow{2}{*}{ Трофоморфи } & \multicolumn{2}{|c|}{ Контроль } & \multicolumn{2}{c|}{ Забрудення } \\
\cline { 2 - 5 } & $\begin{array}{c}\text { проективне } \\
\text { покриття, \% }\end{array}$ & $\begin{array}{c}\text { частка у } \\
\text { структурі, \% }\end{array}$ & $\begin{array}{c}\text { проективне } \\
\text { покриття, \% }\end{array}$ & $\begin{array}{c}\text { частка у } \\
\text { структурі, } \%\end{array}$ \\
\hline $\mathrm{OgTr}$ & 7,59 & 8,50 & 1,43 & 12,22 \\
\hline $\mathrm{OgMsTr}$ & 10,09 & 11,30 & 2,17 & 18,58 \\
\hline $\mathrm{MsTr}$ & 48,95 & 54,81 & 6,17 & 52,81 \\
\hline $\mathrm{MgTr}$ & 21,86 & 24,48 & 1,91 & 16,38 \\
\hline $\mathrm{AlkTr}$ & 0,82 & 0,92 & - & - \\
\hline Усього & 89,32 & 100,00 & 11,69 & 100,00 \\
\hline
\end{tabular}

Домінуючою трофоморфою як в умовах контролю, так і в умовах забруднення, є мезотрофи, що вказує на середньобагаті грунти. При забрудненні з угруповання зникають алькалітрофи, а частка олігомезотрофів - збільшується (з 11,30 до 18,58 \%). Таким чином, загальний трофічний статус едафотопу за умов забруднення не змінюється, але спостерігається тенденція до зменшення ефективної родючості грунту.

За умов контролю угруповання рослин ділянок електричних підстанцій представлено геліофітами та сціогеліофітами (табл. 7). Забруднення грунту призводить до зменшення частки геліофітів ( 44,48 до 37,65 \%), збільшення частки сціогеліофітів (з 55,52 до 58,68 \%) та з'являються геліосціофіти. Таким чином, світловий режим едафтопу можна визнати як напівосвітлений. За умов забруднення він не змінюється, але спостерігається тенденція його трансформації у напрямку до напівтіньового.

\section{Структура геліоморф рослинного покриву територій електричних підстанцій}

\begin{tabular}{|c|c|c|c|c|}
\hline \multirow{2}{*}{ Геліоморфи } & \multicolumn{2}{|c|}{ Контроль } & \multicolumn{2}{c|}{ Забрудення } \\
\cline { 2 - 5 } & $\begin{array}{c}\text { проективне } \\
\text { покриття, \% }\end{array}$ & $\begin{array}{c}\text { частка } \\
\text { у структурі, \% }\end{array}$ & $\begin{array}{c}\text { проективне } \\
\text { покритт, } \%\end{array}$ & частка у структурі, \% \\
\hline $\mathrm{HeSc}$ & - & - & 0,43 & 3,67 \\
\hline $\mathrm{ScHe}$ & 49,59 & 55,52 & 6,86 & 58,68 \\
\hline $\mathrm{He}$ & 39,73 & 44,48 & 4,40 & 37,65 \\
\hline Усього & 89,32 & 100,00 & 11,69 & 100,00 \\
\hline
\end{tabular}

Полленохори в угрупованні представлені переважно анемофілами (запилення відбувається за допомогою вітру) та ентомофілами (за допомогою комах) (табл. 8). Забрудення грунту на полленохоричну структуру угруповання не впливає.

Адаптації рослин, які складають угруповання територій енергетичних підстанцій, до способів розселення діаспор дуже різноманітні.

Серед типів діаспорохорії переважають балісти (76,59 \%). За умов забруднення їх частка знижується (до 64,79 \%). За рахунок цього збільшується частка автохорії (з 1,27 до 2,44 \%), барохорії (з 2,39 до 4,16 \%), епізоохорії (з 0,76 до 3,42 \%) та гідрохорії (з 1,22 до 5,62 \%). 
Таблиия 8

Полленохорична та діаспорохорична структури рослинного покриву територій електричних підстанцій

\begin{tabular}{|c|c|c|c|c|}
\hline \multirow{2}{*}{ Екологічні групи } & \multicolumn{2}{|c|}{ Контроль } & \multicolumn{2}{c|}{ Забрудення } \\
\cline { 2 - 5 } & $\begin{array}{c}\text { проективне } \\
\text { покриття, \% }\end{array}$ & $\begin{array}{c}\text { частка } \\
\text { у структурі, \% }\end{array}$ & $\begin{array}{c}\text { проективне } \\
\text { покриття, \% }\end{array}$ & $\begin{array}{c}\text { частка } \\
\text { структрі, \% }\end{array}$ \\
\hline \multicolumn{5}{|c|}{ Полленохори } \\
\hline Ah & 0,05 & 0,05 & - & - \\
\hline Anph & 51,27 & 57,40 & 6,57 & 56,23 \\
\hline Ent & 38,00 & 42,54 & 5,11 & 43,77 \\
\hline Bсього & 89,32 & 100,00 & 11,69 & 100,00 \\
\hline \multicolumn{5}{|c|}{ Діаспорохори } \\
\hline Ach & 1,14 & 1,27 & 0,29 & 2,44 \\
\hline Anch & 10,50 & 11,76 & 1,43 & 12,22 \\
\hline Bal & 68,41 & 76,59 & 7,57 & 64,79 \\
\hline Bar & 2,14 & 2,39 & 0,49 & 4,16 \\
\hline Bar(Epiz) & 1,32 & 1,48 & 0,29 & 2,44 \\
\hline Endz & 1,23 & 1,37 & - & - \\
\hline Epz & 0,68 & 0,76 & 0,40 & 3,42 \\
\hline Hdch & 1,09 & 1,22 & 0,66 & 5,62 \\
\hline KrGch & 0,23 & 0,25 & 0,03 & 0,24 \\
\hline Myrm & 0,36 & 0,41 & - & - \\
\hline Perv & 1,09 & 1,22 & 0,06 & 0,49 \\
\hline Synz & 1,14 & 1,27 & 0,49 & 4,16 \\
\hline ycboго & 89,32 & 100,00 & 11,69 & 100,00 \\
\hline
\end{tabular}

\section{Висновки.}

1. Ділянки у межах енергетичних підстанцій надають притулок для рослинних угруповань, які характеризуються значним видовим, таксономічним та екологічним різноманіттям. Ці ділянки можуть розглядатися як мікрорефугіуми, які $\epsilon$ осередками для збереження та поширення біологічного різноманіття в умовах антропогенно трансформованих ландшафтів степового Придніпров'я.

2. У межах територій енергетичних підстанцій існують джерела підвищеного антропогенного впливу у вигляді забруднення грунтів технологічною олією. Забруднення грунту може призводити до значного зменшення проективного покриття рослинності.

3. Рослинність енергетичних підстанцій переважно представлена пратантами (46,62 \%) та степантами (29,06 \%). Основними трендами трансформації екологічної структури біогеоценотичного покриву за умов забруднення грунту технологічною олією є збільшення частки однорічних рудерантів, аридизація режиму вологості та збіднення ефективної родючості едафотопу.

\section{Бібліографічні посилання}

1. Бельгард А. Л. Лесная растительность юго-востока УССР. Киев. 1950. 263 с.

2. Бельгард А. Л. Степное лесоведение. Москва. 1971.336 с.

3. Бельгард А. Л., Травлеев $A$. П. Роль почвенной фауны в индикации эдафотопов // Проблемы и методы биологической диагностики и индикации почв. Москва. 1980. C. $155-163$.

4. Бондарь $Г$. А., Жуков А. В. Экологическая структура растительного покрова, сформированного в результате самозарастания дерново-литогенных почв на лессовидных суглинках // Вісник Дніпропетр. держ. аграрного ун-ту. 2011. № 1. С. 54-62. 
5. Антропогенные почвы: генезис, география, рекультивация / М. И. Герасимова и др.; под ред. Г. В. Добровольского. Смоленск. 2003. 268 с.

6. Гиляров М. С. Зоологический метод диагностики почв. Москва. 1965. 276 с.

7. Діуух Я. П. Основи біоіндикації. Київ. 2012. 344 с.

8. Тарасов В. В. Флора Дніпропетровської і Запорізької областей. 2-ге вид., доп. та випр. Дніпропетровськ. 2012. 296 с.

Надійшла до редколегї 14.10.2016 